\title{
The IGSF1 Deficiency Syndrome May Present with Normal Free T4 Levels, Severe Obesity, or Premature Testicular Growth
}

\author{
(D) Steven Ghanny¹, (D) Aliza Zidell1, (D) Helio Pedro1, (D) Sjoerd D. Joustra², (D) Monique Losekoot³, (D) Jan M. Wit², (D) Javier Aisenberg1 \\ 1 Hackensack University Medical Center, Department of Pediatrics, Hackensack, United States \\ 2 Leiden University Medical Center, Department of Pediatrics, Leiden, The Netherlands \\ ${ }^{3}$ Leiden University Medical Center, Department of Clinical Genetics, Leiden, The Netherlands
}

\begin{abstract}
What is already known on this topic?
Almost all individuals with IGSF1 deficiency have central hypothyroidism. Almost all individuals with IGSF1 deficiency show disharmonious pubertal development and macroorchidism in adulthood, but premature testicular growth is rare. Individuals with IGSF1 deficiency tend to be overweight, but extreme early-onset obesity has only been reported once.
\end{abstract}

\section{What this study adds?}

IGSF1 deficiency can present with free thyroxine levels above the lower limit of normal. Premature testicular growth without elevated serum testosterone can be a sign of IGSF1 deficiency. The extreme weight gain in this and a previous case suggests that this is part of the clinical spectrum of IGSF1 deficiency syndrome.

\section{Abstract}

Our objective was to further expand the spectrum of clinical characteristics of the IGSF1 deficiency syndrome in affected males. These characteristic include almost universal congenital central hypothyroidism (CeH) with disharmonious pubertal development (normally timed testicular growth, but delayed rise of serum testosterone), macroorchidism, increased body mass index (BMI), and decreased attentional control. In addition, a subset of patients show prolactin deficiency, transient partial growth hormone deficiency in childhood and increased growth hormone secretion in adulthood. We present a family in which the proband was diagnosed with CeH and low serum prolactin. Severe weight gain started at two years old, with a BMI of 42.3 at 13.9 years. Testicular enlargement (5-6 mL, 3.8-4.3 standard deviation score) started aged three years. A pathogenic variant was found in the IGSF1 gene: c.3411_3412del, p.(Tyr1137*). His brother was referred for short stature at age 13 years and was diagnosed with $\mathrm{CeH}$, normal serum prolactin and IGF-1, and disharmonious puberty. In four male relatives (the proband's brother and three cousins) with the variant (one adult), free thyroxine (fT4) was below the lower limit of the reference range in two, and just above this limit in the other two. Three were overweight or obese, adolescents had disharmonious pubertal development and the adult had profound macroorchidism. In conclusion, male hemizygous carriers of a pathogenic IGSF1 variant can present with fT4 concentration above the lower limit of the reference range while severe early onset obesity or premature testicular growth are part of the phenotypic spectrum.

Keywords: IGSF1 deficiency, hypothyroidism, macroorchidism, obesity, prolactin

\section{Introduction}

Central hypothyroidism $(\mathrm{CeH})$ is a rare disorder characterized by a low serum free thyroxine (fT4) concentration and inappropriately low or normal thyroid stimulating hormone (TSH) levels (1). Acquired $\mathrm{CeH}$ is often part of multiple pituitary deficiency, for example due to compressive lesions, cranial surgery or irradiation, or injury. Congenital $\mathrm{CeH}$ is usually part of multiple pituitary hormone deficiency, but can also be isolated; both forms can be caused by genetic defects $(1,2)$.
Address for Correspondence: Steven Ghanny MD, Hackensack University Medical Center, Department of Pediatrics, Hackensack, United States

Phone: +551-996-5329 E-mail: steven.ghanny@hackensackmeridian.org ORCID: orcid.org/0000-0002-3901-4464
Conflict of interest: None declared Received: 01.07 .2020 Accepted: 29.09.2020

${ }^{\oplus}$ Copyright 2021 by Turkish Pediatric Endocrinology and Diabetes Society

The Journal of Clinical Research in Pediatric Endocrinology published by Galenos Publishing House. 
Usually, cases with the congenital form are not diagnosed shortly after birth, because most newborn screening programs in the world are based on the detection of elevated TSH values only. Even in the few countries and states where screening programs are based on a combination of TSH and $\mathrm{T} 4$, some cases of congenital $\mathrm{CeH}$ can remain undiagnosed for many years, because of borderline low T4 levels (3).

Recently, immunoglobulin superfamily, member 1 (IGSF1) deficiency (MIM \#300888) emerged as a novel cause of congenital $\mathrm{CeH}$ (4), and is now considered the most prevalent cause of congenital $\mathrm{CeH}$ (5). IGSF1 encodes a glycoprotein that is located on the membrane of various cell types and the transcript is abundantly expressed in the rodent pituitary gland and testis $(4,6)$. Deficiency of this protein in the human male causes X-linked $\mathrm{CeH}$, disharmonious pubertal development (normal timing of testicular growth, but delayed rise of testosterone) and macroorchidism. In a variable proportion of affected males other features are observed, including prolactin deficiency, partial and transient growth hormone $(\mathrm{GH})$ deficiency in childhood, increased body mass index (BMI), and decreased attentional control $(4,7,8$, $9,10,11,12,13,14,15,16,17,18,19)$. Mean follicle stimulating hormone (FSH) and $\mathrm{GH}$ secretion are increased in some affected males $(20,21)$.

We present a male index case with $\mathrm{CeH}$, premature testicular growth, and severe, early-onset obesity, associated with a hemizygous nonsense variant in IGSF1 [c.3411_3412del, p.(Tyr $\left.1137^{*}\right)$ ], as well as variable phenotypes observed in four male relatives carrying the variant, including normal fT4 concentrations. The large variation in clinical and biochemical findings in affected males in this pedigree shows that the phenotype of IGSF1 deficiency is even broader than has so far been reported $(4,7,8,9,10,11,12,13,14,15,16,17$, $18,19)$, and may include a serum fT4 concentration above the lower limit of the reference range, premature testicular growth and severe early-onset obesity.

\section{Case Report}

\section{Proband}

The proband was born full term after an uncomplicated vaginal delivery, with a birth weight of 4082 grams [1.1 standard deviation (SD) score (SDS)] and length of 52.1 $\mathrm{cm}$ (0.8 SDS) (22). He was admitted to the neonatal unit for hyperbilirubinemia four days after birth. Newborn screening using TSH and T4 showed $\mathrm{CeH}$ (T4 $<77.2 \mathrm{nmol} / \mathrm{L}$ and TSH $<20 \mathrm{mIU} / \mathrm{L}$ which are the cut-off limits in the available screening program). These results were confirmed by a blood draw at four weeks of age when the T4 was
$52.9 \mathrm{nmol} / \mathrm{L}$ (reference range $58.1-154.8 \mathrm{nmol} / \mathrm{L}$ ) and the TSH was $1.7 \mathrm{mIU} / \mathrm{L}$ (reference range 0.8-19.2 nmol/L). At seven weeks old, thyroid hormone replacement was started at $7.4 \mu \mathrm{g} / \mathrm{kg} /$ day. An extensive pituitary examination was performed, showing an undetectable serum prolactin level and normal serum levels of insulin-like growth factor 1 (IGF1) and cortisol. No structural abnormalities were observed with magnetic resonance imaging of the pituitary.

At 2.4 years of age, he was obese (BMI $20.3 \mathrm{~kg} / \mathrm{m}^{2}, 2.4$ SDS) (22). At follow-up, normal linear growth and further excessive weight gain was noted with a maximum at 13.9 years of age, when weight was $125.2 \mathrm{~kg}$ with a BMI of $42.3\left[163 \%\right.$ of the $95^{\text {th }}$ US percentile (22) and 4.2 SDS for a 1980 European reference (23), Figures $1 \mathrm{~A}$ and 1B]. Thyroid hormone treatment was interrupted between the ages of 2.8 and 3.4 years due to proband's mother stopping medication, but has been administered since. Serum fT4 levels have been maintained in the lower half of the reference range (Table 1).

His testicular volume assessed with Prader orchidometer was $2 \mathrm{~mL}$ at 2.4 years (0.9 SDS) (24), but showed a remarkable enlargement to $5-6 \mathrm{~mL}$ at a follow-up visit at 3.4 years old (3.8-4.3 SDS) (Figure 2A), without pubic hair appearance or linear growth acceleration. At 6.3 years, a testicular ultrasound was performed, showing right and left testicular volumes of 6.3 and $5.8 \mathrm{~mL}$ [4.2 SDS, reference range at that age 0.3 to $1.1 \mathrm{~mL}(24)]$, still in the absence of pubic hair, and with undetectable plasma testosterone. A gonadotropin releasing hormone $(\mathrm{GnRH})$ stimulation test showed a pre-pubertal pituitary response with baseline and peak luteinising hormone (LH) of 0.09 and $3 \mathrm{IU} / \mathrm{L}$ and a baseline and peak FSH of 0.95 and 16 IU/L. A borderline pubertal response to GnRH was first observed at 9.4 years old (baseline and stimulated serum LH of 0.3 and $7 \mathrm{IU} / \mathrm{L}$; FSH of 2 and $17.9 \mathrm{IU} / \mathrm{L}$ ), when his testicular size was 10-12 $\mathrm{mL}$ (3.5-3.8 SDS). However, plasma testosterone was still undetectable, and baseline and stimulated FSH secretion surpassed LH secretion. Further clinical and laboratory data are shown in Table 1. Reference data for serum testosterone in minipuberty (1-3 months) and Tanner stage were derived from the literature $(25,26)$. A thyroid ultrasound at 12.5 years showed a symmetrically small gland, with an estimated volume of less than $1 \mathrm{~mL}$ for each lobe. Bone age was close to chronological age (27).

\section{Genetic Analysis}

Fragile $\mathrm{X}$ testing was negative, the methylation pattern of SNRPN was not suggestive of Prader-Willi syndrome, and the array comparative genomic hybridization $(\mathrm{CGH})$ was normal. However, a pathogenic variant (nonsense mutation) 


\begin{tabular}{|c|c|c|c|c|c|c|c|c|c|c|}
\hline Age (years) & 0.10 & 0.13 & 0.20 & 0.92 & 2.0 & 3.40 & 6.30 & 7.60 & 9.40 & Reference range \\
\hline Bone age (years) ${ }^{a}$ & & & & & & & 6.1 & 7.5 & & \\
\hline Height SDS ${ }^{\mathrm{b}}$ & & & & & 0.3 & 0.1 & 0.3 & 0.4 & 1.2 & \\
\hline BMI & & & & & 20.4 & 22.5 & 25.1 & 27.3 & 28.9 & \\
\hline BMI SDS ${ }^{\mathrm{b}}$ & & & & & 2.4 & 3.9 & 2.9 & 2.6 & 2.4 & \\
\hline Testicular volume $(\mathrm{mL})^{c}$ & & & 2 & & 2 & $5-6$ & 8 & $8-10$ & $10-12$ & \\
\hline TSH (mIU/L) & 1.75 & 3.2 & 0.02 & 0.46 & & 1.4 & $<0.01$ & & $<0.01$ & $0.8-6.3$ \\
\hline Prolactin (nmol/L) & & & 3 & & & & & & $<1$ & $2-18$ \\
\hline Testosterone (nmol/L) & & & $14.0^{\mathrm{e}}$ & & & & & & $<0.2^{\mathrm{f}}$ & Age dependent \\
\hline Levothyroxine dose (ug/kg/day) & & 7.4 & 5.5 & 2.7 & 1.5 & $\begin{array}{l}\text { Stopped } 2.8 \text { - } \\
3.4 \text { years }\end{array}$ & 2.1 & 1.7 & 1.1 & \\
\hline
\end{tabular}

${ }^{a}$ Assessed by the atlas of Greulich and Pyle (27).

${ }^{\mathrm{b}}$ Based on Centers for Disease Control reference (22).

${ }^{\mathrm{c}}$ Assessed by the Prader orchidometer.

${ }^{\mathrm{d} S}$ Sample taken before start of L-thyroxine treatment.

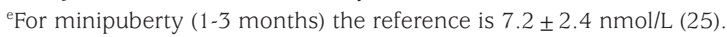

${ }^{\mathrm{f}}$ For Tanner stage 1 the reference range is $<0.3-0.5 \mathrm{nmol} / \mathrm{L}(27)$.

SDS: standard deviation score, BMI: body mass index, FT4: free thyroxine, TSH: thyroid stimulating hormone

in the IGSF1 gene [NM_00117096.1: c.3411_3412del, p. (Tyr $\left.\left.1137^{*}\right)\right]$ was detected by Sanger sequencing $(4,10,11)$. Segregation analysis showed that the mutation was also present in three female and five male family members (Figure 2B).

\section{Relatives Carrying the IGSF1 Variant}

The proband was the second child of reportedly healthy parents of Italian descent (Figure 2B). Clinical and laboratory findings are shown in Table 2.

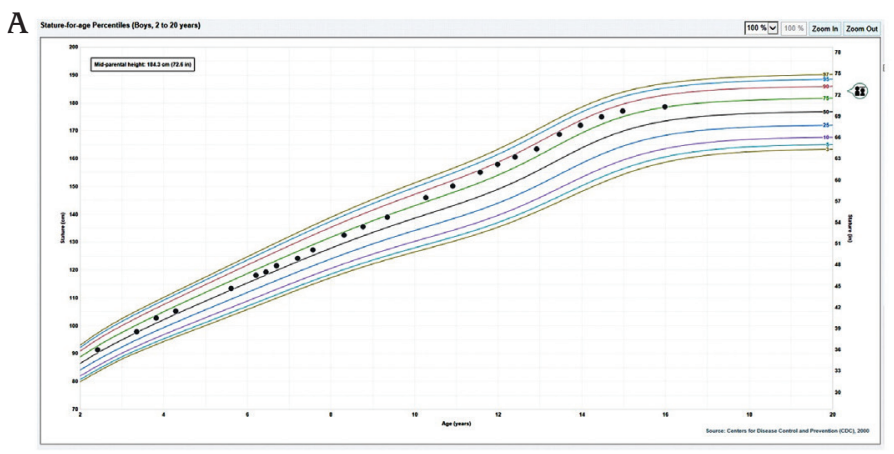

B

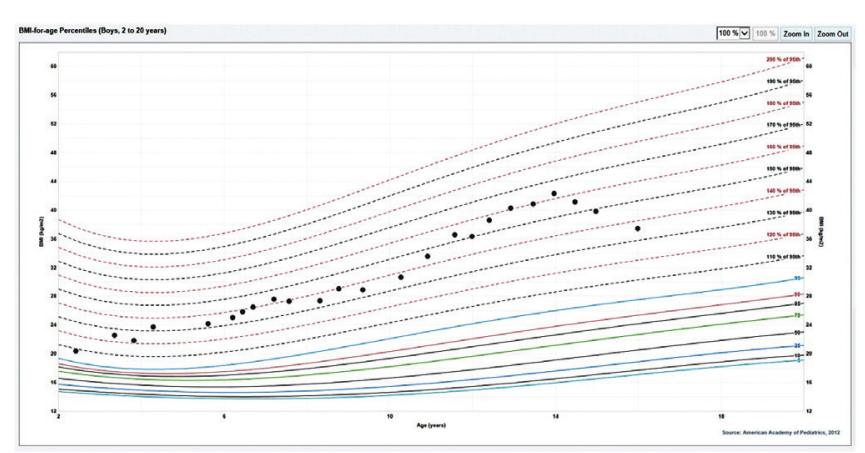

Figure 1. Height (panel A) and body mass index (panel B) for age of proband plotted on Centers for Disease Control charts (22)
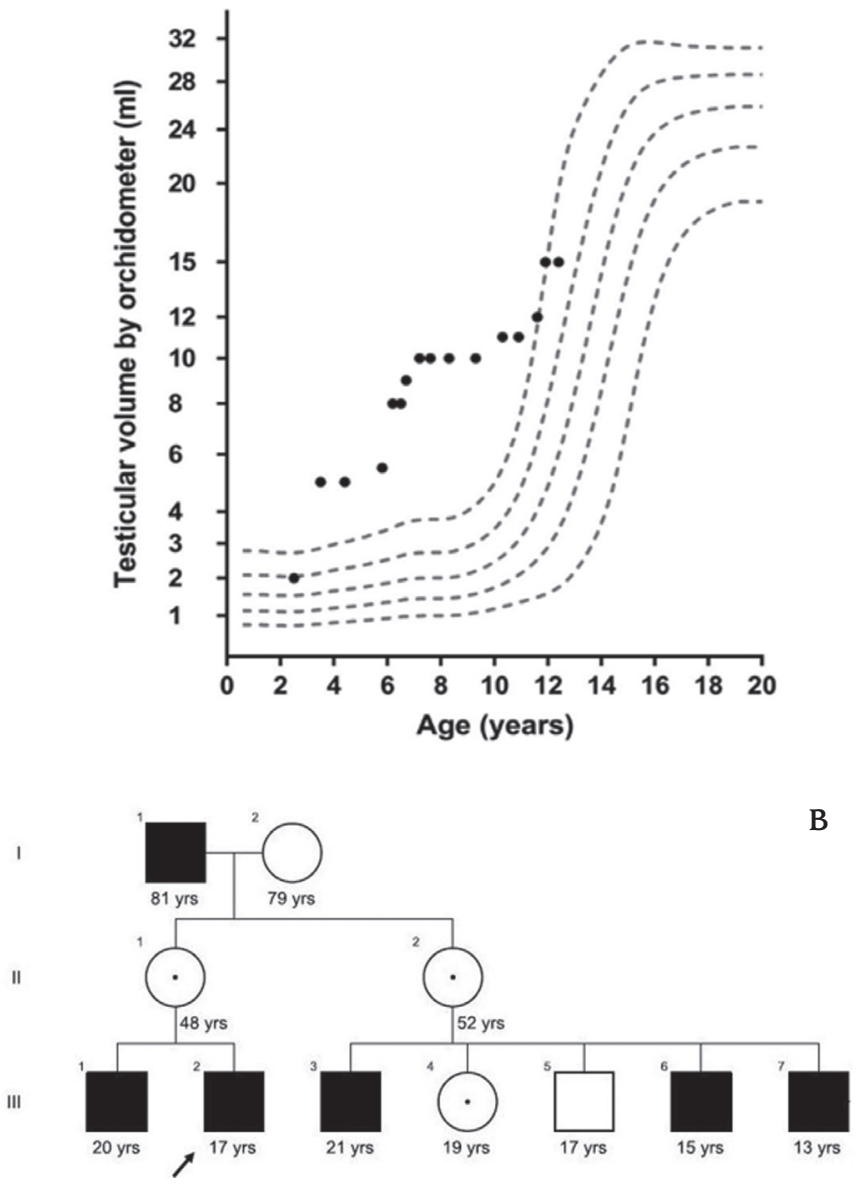

Figure 2. Panel A: Testicular growth as assessed by orchidometer in the proband plotted on reference charts according to Joustra et al (24). Panel B: Pedigree. The arrow indicates the proband. Solid squares indicate hemizygous carriers. Black dots signify heterozygous female carriers 
The proband's older brother (case III-1) was seen at the clinic at the age of 13 years, after the proband's initial findings. He had a normal TSH and fT4 newborn screening result. At presentation, besides $\mathrm{CeH}$ with thyroid function test (TFTs) results of fT4 $9.0 \mathrm{pmol} / \mathrm{L}$ (reference range 11.620.6) and TSH $1.54 \mathrm{mIU} / \mathrm{L}$ (reference range 0.5-4.3)], he had a low plasma testosterone level in contrast to a testicular size of 25-28 mL (2.1-2.3 SD). His serum prolactin and IGF1 levels were normal, as was his height and BMI, and he did not have any manifestations of long-standing untreated hypothyroidism. He subsequently started levothyroxine at 1 $\mu \mathrm{g} / \mathrm{kg} / \mathrm{day}$, which led to normalization of his fT4.

The first male cousin (case III-3, 20 years old) showed $\mathrm{CeH}$, obesity, macroorchidism (50 mL), and attention issues at school. Initial TFTs showed a low fT4 of $9.7 \mathrm{pmol} / \mathrm{L}$ (reference range: 11.9-20.6) and inappropriately low TSH of $1.01 \mathrm{mIU} / \mathrm{L}$. TFTs were repeated and showed a slightly higher fT4 (10.68 pmol/L), which was just above the lower limit of reference range of the fT 4 assay in use at the time (10.55-22.78 pmol/L), with a concurrent TSH of 0.715 $\mathrm{mIU} / \mathrm{L}$. The patient did not start levothyroxine treatment.

The second affected male cousin (case III-6, 14.3 years old) showed a fT4 just above the lower limit of the reference range at $12 \mathrm{pmol} / \mathrm{L}$ (reference range: 11.9-20.6) with normal TSH levels, and obesity. At 14.3 years his testes were of appropriate size for age (10-12 mL, -0.8 to $-0.4 \mathrm{SDS})$. On ultrasound, testicular volumes were 17 and $12 \mathrm{~mL},(2.4$ and 1.4 SDS, respectively) (24), which contrasted with the low plasma testosterone. The ultrasound also showed some peri-testicular fluid and microlithiasis.

The third affected male cousin (case III-7, 11.4 years old) also showed a serum fT4 just above the lower limit of the reference range at $12.7 \mathrm{pmol} / \mathrm{L}$ (reference range: 11.9-20.6 pmol/L) with normal TSH levels, and was also obese. He had difficulties at school with reading comprehension. At 11.4 years of age, his testicular volume (5-6 mL) was larger than expected for the pre-pubertal pubic hair Tanner stage.

The proband's mother and female cousin, who were heterozygous for the IGSF1 variant, showed a serum fT4 of $12.9 \mathrm{pmol} / \mathrm{L}$ and $16.7 \mathrm{pmol} / \mathrm{L}$, respectively (reference range: 11.9-20.6) Their menarcheal ages were 10 years and 11.5 years, respectively, and they both had normal menstrual cycles. Clinical data for one male patient and one female carrier were not available (cases I-1 and II-2).

For all patients discussed in this article, blood work-up and examinations were performed within the normal standard

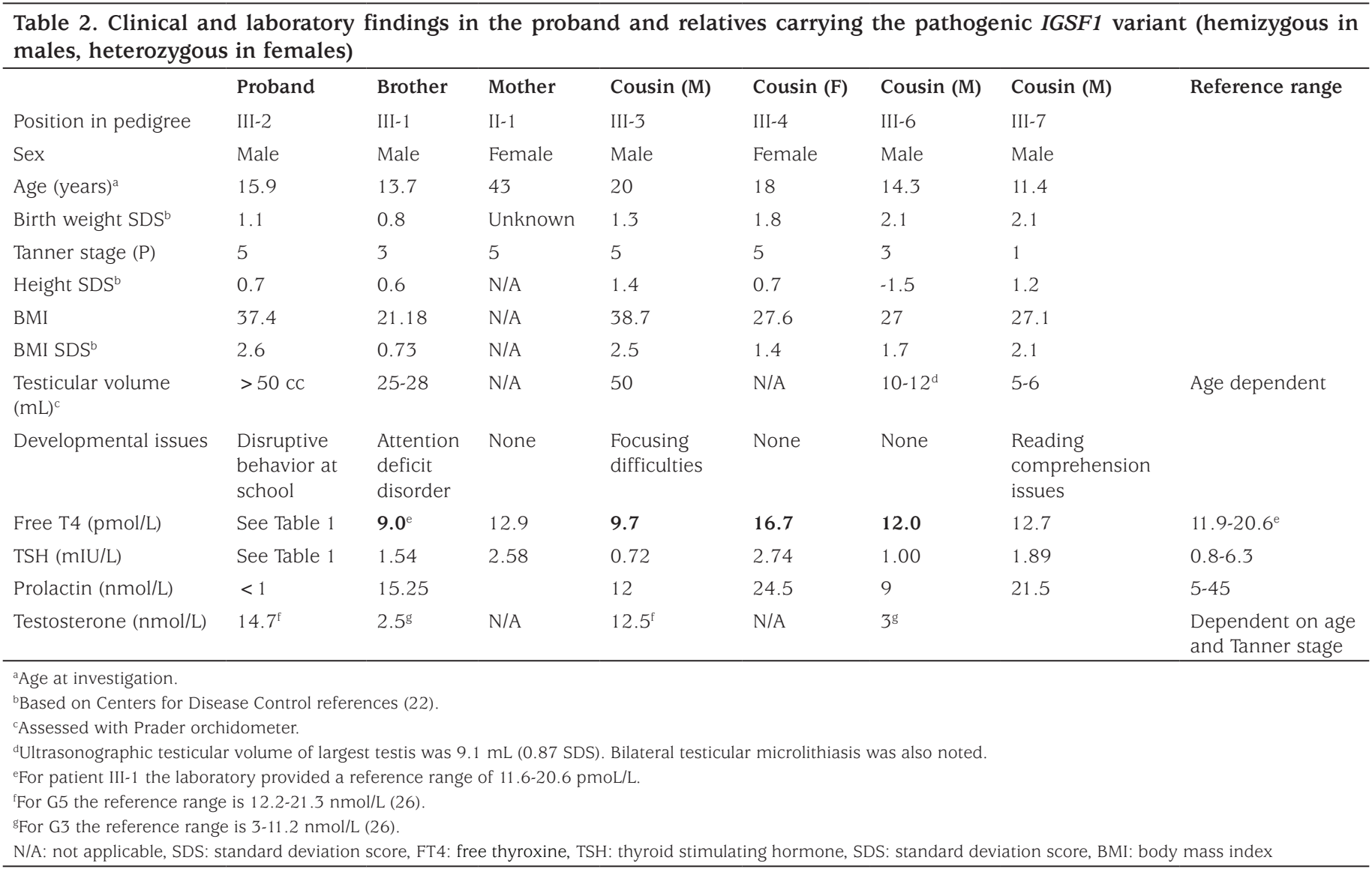


of care. Informed consent (and assent, if appropriate) was obtained for all genetic testing that was completed. For patients below the age of 18 years, an informed assent and consent was obtained, as appropriate. For patients above 18 years of age, an informed consent was obtained. Limited data concerning the proband, his elder brother and his mother were previously published as part of a large case series (11), and did not include the proband's early obesity or very early testicular growth.

\section{Discussion}

Here, we describe a patient who presented initially with neonatal jaundice, $\mathrm{CeH}$ and low serum prolactin, and later showed severe obesity, premature testicular growth, disharmonious pubertal development, disruptive behavior at school, and macroorchidism. Genetic evaluation showed a pathogenic variant in the IGSF1 gene [c.3411_3412del, p. (Tyr $\left.1137^{*}\right)$ ]. Further evaluation of the family showed that the proband's brother and three out of four male maternal cousins carried the same variant. Their fT 4 levels were just below or, in three cases, just above the lower limit of the reference range at first or second testing. Macroorchidism was also present in two young adult male relatives. In the two adolescents, testicular volume was large compared to Tanner stage and plasma testosterone, consistent with disharmonious pubertal development. Serum prolactin was decreased only in the proband, compared with approximately $60 \%$ of patients in earlier reports (11). Birth weight was between 0.8 and 2.1 SDS in male carriers.

In this family, there are three clinical observations that are unusual when compared to previously reported families. First, in virtually all patients with IGSF1 deficiency reported to date, the serum fT4 concentration is decreased in combination with a normal or low serum TSH, while the occurrence of other clinical and laboratory features is more variable $(4,7,8,9,10,11,12,14,16,17,18)$. Serum fT4 levels have been reported to be just above the lower limit of reference range $(13,15)$ or fluctuating around it (19) in only two and one male patients, respectively. In the present report, we show that out of four male relatives of the proband, fT4 levels were just above the lower limit of normal in two of them, and fluctuated around the lower limit in a third case, suggesting that this may occur more often in males with IGSF1 deficiency than previously assumed.

Second, the start of testicular growth in the proband from two years of age was unusually early, possibly associated with relatively high serum FSH concentrations before and after stimulation by GnRH. A similarly early onset, but less extreme testicular growth $(3 \mathrm{~mL}$ with the Prader orchidometer) with increased FSH levels has been recorded only once in a 3-year-old boy with a hemizygous IGSF1 deletion (28). In adult male patients, 24-hour FSH secretion is generally increased, although within the normal range (11).

Third, although obesity has been observed in $21 \%$ of children and $17 \%$ of adult males (11), extreme early weight gain, as was present in the proband, is unusual. Only one previous report of a 2-year-old patient with IGSF1 deficiency showed such severe obesity (4.2 SDS) (16). In our report, obesity was also observed in three of the four proband's male relatives carrying the IGSF1 variant. It is currently unknown why IGSF1 deficiency is associated with increased BMI, and in rare cases also with extreme body weight gain. One might speculate that intracellular thyroid hormone concentration or thyroid hormone dependent gene translation are defective in the adipose tissue of these patients. Alternatively, obesity may be caused by decreased fat-burning non-shivering thermogenesis given the role of thyrotropin releasing hormone (TRH) in the central regulation of brown adipose fat functioning and the decreased expression of the pituitary TRH receptor in IGSF1 knockout mice (4). We have not been able to formally test signs of tissue hypothyroidism or thermogenesis.

The occurrence of other clinical features, such as relatively high birth weight, prolonged neonatal jaundice, as well as the variability of clinical features within one family, are consistent with previous reports $(4,7,8,9,10,11,12,13,14,15,16,17,18$, 19). For example, birth weight was relatively high (0.8-2.1 SDS), in the upper half of what has been reported for other cohorts $(9,11)$. Macroorchidism was seen in the three adult males and disharmonious puberty in the two adolescents, as reported in virtually all cases so far (11). Mild neurological findings, such as attention deficit and difficulties with reading and focusing, were present in three members of this family, in line with observations in a larger cohort (12).

The phenotypic differences within this family are intriguing, and this has been observed in all previously published families (11). In the proband, CGH and testing for Prader-Willi and fragile $\mathrm{X}$ syndrome were normal. In previously published families, whole exome/genome sequencing did not reveal other genetic defects that explain these differences. We speculate that polymorphisms or (variable penetrance of) epigenetic changes account for the phenotypic differences.

The pathophysiology of the IGSF1 deficiency syndrome is currently unknown, but may include reduced expression of the receptor for TRH and impaired TRH stimulation of thyrotropin secretion (29). The macroorchidism seen in these patients may be associated with increased FSH 
secretion (20). Alternatively, the usual tri-iodothyroninedependent pubertal increase in LH receptors and cessation of Sertoli cell proliferation could be affected in these patients (despite treatment with levothyroxine), causing a delay in pubertal testosterone rise in the presence of macroorchidism (30). The prolactin and GH deficiency may be related to effects on pituitary transcription factors, such as Pit-1 or TRH receptivity (2). The cause of the obesity seen in these patients has not been elucidated, and there seems to be no association between fT4 levels and the degree of overweight (11). Similarly, it is uncertain whether the issues with attentional control seen in these patients may be associated with timing of levothyroxine treatment (11).

\section{Conclusion}

In conclusion, this report demonstrates that male hemizygous carriers of a pathogenic IGSF1 variant can present with fT 4 levels above the lower limit of the reference range; that premature testicular growth without increased testosterone concentrations may be part of the spectrum of clinical features; and that severe early onset obesity may be part of the phenotypic spectrum. This would imply that testing for IGSF1 should not only be considered in patients who have $\mathrm{CeH}$ of unknown cause and low prolactin, macroorchidism, or delayed puberty (11), but also when serum fT4 is slightly above the lower limit of normal and in cases with premature testicular growth or unexplained early-onset obesity. We endorse the advice to test family members in a pattern consistent with X-linked inheritance, if a proband is diagnosed with IGSF1 deficiency, because of the indirect evidence that levothyroxine treatment has a positive effect (11) and in order to obtain more information about the scope of the clinical and laboratory characteristics of this still enigmatic syndrome.

\section{Ethics}

Informed Consent: Informed consent (and assent, if appropriate) was obtained for all genetic testing that was completed.

\section{Peer-review: Externally peer-reviewed.}

\section{Authorship Contributions}

Surgical and Medical Practices: Javier Aisenberg, Steven Ghanny, Aliza Zidell, Helio Pedro, Monique Losekoot, Concept: Javier Aisenberg, Steven Ghanny, Design: Javier Aisenberg, Steven Ghanny, Jan M. Wit, Sjoerd D. Joustra, Data Collection or Processing: Javier Aisenberg, Steven Ghanny, Aliza Zidell, Helio Pedro, Analysis or Interpretation: Javier Aisenberg, Steven Ghanny, Aliza Zidell, Helio Pedro, Jan M.
Wit, Sjoerd D Joustra, Literature Search: Javier Aisenberg, Steven Ghanny, Jan M. Wit, Sjoerd D Joustra, Writing: Javier Aisenberg, Steven Ghanny, Jan M. Wit, Sjoerd D Joustra.

Financial Disclosure: The authors declared that this study received no financial support.

\section{References}

1. Schoenmakers N, Alatzoglou KS, Chatterjee VK, Dattani MT. Recent advances in central congenital hypothyroidism. J Endocrinol 2015;227:R51-71. Epub 2015 Sep 28

2. Persani L, Bonomi M. The multiple genetic causes of central hypothyroidism. Best Pract Res Clin Endocrinol Metab. 2017;31:255 263. Epub 2017 Apr 17

3. Kempers MJ, Lanting CI, van Heijst AF, van Trotsenburg AS, Wiedijk BM, de Vijlder JJ, Vulsma T. Neonatal screening for congenital hypothyroidism based on thyroxine, thyrotropin, and thyroxinebinding globulin measurement: potentials and pitfalls. J Clin Endocrinol Metab 2006;91:3370-3376. Epub 2006 Jun 20

4. Sun Y, Bak B, Schoenmakers N, van Trotsenburg AS, Oostdijk W, Voshol P, Cambridge E, White JK, le Tissier P, Gharavy SN, MartinezBarbera JP, Stokvis-Brantsma WH, Vulsma T, Kempers MJ, Persani L, Campi I, Bonomi M, Beck-Peccoz P, Zhu H, Davis TM, Hokken-Koelega AC, Del Blanco DG, Rangasami JJ, Ruivenkamp CA, Laros JF, Kriek M, Kant SG, Bosch CA, Biermasz NR, Appelman-Dijkstra NM, Corssmit EP, Hovens GC, Pereira AM, den Dunnen JT, Wade MG, Breuning MH, Hennekam RC, Chatterjee K, Dattani MT, Wit JM, Bernard DJ. Loss-offunction mutations in IGSF1 cause an X-linked syndrome of central hypothyroidism and testicular enlargement. Nat Genet 2012;44:1375 1381. Epub 2012 Nov 11

5. Persani L, Brabant G, Dattani M, Bonomi M, Feldt-Rasmussen U, Fliers E, Gruters A, Maiter D, Schoenmakers N, van Trotsenburg ASP. 2018 European Thyroid Association (ETA) Guidelines on the Diagnosis and Management of Central Hypothyroidism. Eur Thyroid J 2018;7:225237. Epub 2018 Jul 19

6. Joustra SD, Meijer OC, Heinen CA, Mol IM, Laghmani el H, Sengers RM, Carreno G, van Trotsenburg AS, Biermasz NR, Bernard DJ, Wit JM, Oostdijk W, van Pelt AM, Hamer G, Wagenaar GT. Spatial and temporal expression of immunoglobulin superfamily member 1 in the rat. J Endocrinol 2015;226:181-191. Epub 2015 Jul 10

7. Tajima T, Nakamura A, Ishizu K. A novel mutation of IGSF1 in a Japanese patient of congenital central hypothyroidism without macroorchidism. Endocr J 2013;60:245-249. Epub 2013 Jan 30

8. Nakamura A, Bak B, Silander TL, Lam J, Hotsubo T, Yorifuji T, Ishizu $\mathrm{K}$, Bernard DJ, Tajima T. Three novel IGSF1 mutations in four Japanese patients with X-linked congenital central hypothyroidism. J Clin Endocrinol Metab 2013;98:E1682-e1691. doi: 10.1210/jc.2013-1224. Epub 2013 Aug 21

9. Asakura Y, Abe K, Muroya K, Hanakawa J, Oto Y, Narumi S, Hasegawa $\mathrm{T}$, Adachi M. Combined growth hormone and thyroid-stimulating hormone deficiency in a japanese patient with a novel frameshift mutation in IGSF1. Horm Res Paediatr 2015;84:349-354. Epub 2015 Aug 19

10. Joustra SD, Schoenmakers N, Persani L, Campi I, Bonomi M, Radetti G, Beck-Peccoz P, Zhu H, Davis TM, Sun Y, Corssmit EP, AppelmanDijkstra NM, Heinen CA, Pereira AM, Varewijck AJ, Janssen JA, Endert E, Hennekam RC, Lombardi MP, Mannens MM, Bak B, Bernard DJ, Breuning $\mathrm{MH}$, Chatterjee $\mathrm{K}$, Dattani MT, Oostdijk W, Biermasz NR, Wit JM, van Trotsenburg AS. The IGSF1 deficiency syndrome: 
characteristics of male and female patients. J Clin Endocrinol Metab 2013;98:4942-4952. Epub 2013 Oct 9

11. Joustra SD, Heinen CA, Schoenmakers N, Bonomi M, Ballieux BE, Turgeon MO, Bernard DJ, Fliers E, van Trotsenburg AS, Losekoot M, Persani L, Wit JM, Biermasz NR, Pereira AM, Oostdijk W; IGSF1 Clinical Care Group. IGSF1 deficiency: lessons from an extensive case series and recommendations for clinical management. J Clin Endocrinol Metab 2016;101:1627-1636. Epub 2016 Feb 3

12. Joustra SD, Andela CD, Oostdijk W, van Trotsenburg AS, Fliers E, Wit JM, Pereira AM, Middelkoop HA, Biermasz NR. Mild deficits in attentional control in patients with the IGSF1 deficiency syndrome. Clin Endocrinol (Oxf) 2016;84:896-903. Epub 2015 Oct 15

13. Hughes JN, Aubert M, Heatlie J, Gardner A, Gecz J, Morgan T, Belsky $J$, Thomas PQ. Identification of an IGSF1-specific deletion in a fivegeneration pedigree with X-linked Central Hypothyroidism without macroorchidism. Clin Endocrinol (Oxf) 2016;85:609-615. Epub 2016 Jun 9

14. Tenenbaum-Rakover Y, Turgeon MO, London S, Hermanns P, Pohlenz J, Bernard DJ, Bercovich D. Familial central hypothyroidism caused by a novel IGSF1 gene mutation. Thyroid 2016;26:1693-1700. Epub 2016 Jul 25

15. Nishigaki S, Hamazaki T, Fujita K, Morikawa S, Tajima T, Shintaku H. A Japanese family with central hypothyroidism caused by a novel IGSF1 Mutation. Thyroid 2016;26:1701-1705. Epub 2016 Nov 21

16. Roche EF, McGowan A, Koulouri O, Turgeon MO, Nicholas AK, Heffernan E, El-Khairi R, Abid N, Lyons G, Halsall D, Bonomi M, Persani L, Dattani MT, Gurnell M, Bernard DJ, Schoenmakers N. A novel IGSF1 mutation in a large Irish kindred highlights the need for familial screening in the IGSF1 deficiency syndrome. Clin Endocrinol (Oxf) 2018;89:813-823. Epub 2018 Oct 1

17. Yamaguchi T, Hothubo T, Morikawa S, Nakamura A, Mori T, Tajima T. A Japanese patient with congenital central hypothyroidism caused by a novel IGSF1 mutation. J Pediatr Endocrinol Metab 2018;31:355-359.

18. Oguma M, Kobayashi M, Yamazaki M, Yokoyama K, Morikawa S, Yamaguchi T, Yamagata T, Tajima T. Two siblings with congenital central hypothyroidism caused by a novel mutation in the IGSF1 gene. Clin Pediatr Endocrinol 2018;27:95-100. Epub 2018 Apr 13

19. Papadimitriou A, Papadopoulou A, Kleanthous K, Papadimitriou DT, Papaevangelou V. Hypoprolactinemia as a clue to diagnosis of mild central hypothyroidism due to IGSF1 deficiency. J Clin Res Pediatr Endocrinol 2020;12:218-222. Epub 2019 Aug 26

20. Joustra SD, Roelfsema F, Endert E, Ballieux BE, van Trotsenburg AS, Fliers E, Corssmit EP, Bernard DJ, Oostdijk W, Wit JM, Pereira AM,
Biermasz NR. Pituitary hormone secretion profiles in IGSF1 Deficiency syndrome. Neuroendocrinology 2016;103:408-416. Epub 2015 Aug 25

21. Joustra SD, Roelfsema F, van Trotsenburg ASP, Schneider HJ, Kosilek RP, Kroon HM, Logan JG, Butterfield NC, Zhou X, Toufaily C, Bak B, Turgeon MO, Brûlé E, Steyn FJ, Gurnell M, Koulouri O, Le Tissier P, Fontanaud P, Duncan Bassett JH, Williams GR, Oostdijk W, Wit JM, Pereira AM, Biermasz NR, Bernard DJ, Schoenmakers N. IGSF1 Deficiency results in human and murine somatotrope neurosecretory hyperfunction. J Clin Endocrinol Metab 2020;105:e70-e84.

22. Kuczmarski RJ, Ogden CL, Grummer-Strawn LM, Flegal KM, Guo SS, Wei R, Mei Z, Curtin LR, Roche AF, Johnson CL. CDC growth charts: United States. Adv Data 2000:1-27.

23. Cole TJ, Roede MJ. Centiles of body mass index for Dutch children aged 0-20 years in 1980--a baseline to assess recent trends in obesity. Ann Hum Biol 1999;26:303-308.

24. Joustra SD, van der Plas EM, Goede J, Oostdijk W, Delemarre-van de Waal HA, Hack WW, Hack WW, van Buuren S, Wit JM. New reference charts for testicular volume in Dutch children and adolescents allow the calculation of standard deviation scores. Acta Paediatr 2015;104:e271-e278. Epub 2015 Mar 11.

25. Forest MG, Sizonenko PC, Cathiard AM, Bertrand J. Hypophysogonadal function in humans during the first year of life. 1. Evidence for testicular activity in early infancy. J Clin Invest 1974;53:819-828.

26. Crofton PM, Evans AE, Groome NP, Taylor MR, Holland CV, Kelnar CJ. Inhibin $\mathrm{B}$ in boys from birth to adulthood: relationship with age, pubertal stage, FSH and testosterone. Clin Endocrinol (Oxf) 2002;56:215-221.

27. Greulich WW, Pyle SJ. Radiographic atlas of skeletal development of the hand and wrist. 2 ed. California, Stanford University Press, 1959.

28. Garcia M, Barrio R, Garcia-Lavandeira M, Garcia-Rendueles AR, Escudero A, Diaz-Rodriguez E, Gorbenko Del Blanco D, Fernández A, de Rijke YB, Vallespín E, Nevado J, Lapunzina P, Matre V, Hinkle PM, Hokken-Koelega AC, de Miguel MP, Cameselle-Teijeiro JM, Nistal M, Alvarez CV, Moreno JC. The syndrome of central hypothyroidism and macroorchidism: IGSF1 controls TRHR and FSHB expression by differential modulation of pituitary TGFbeta and Activin pathways. Sci Rep 2017;7:42937.

29. Bernard DJ, Brule E, Smith CL, Joustra SD, Wit JM. From consternation to revelation: discovery of a role for IGSF1 in pituitary control of thyroid function. J Endocr Soc 2018;2:220-231.

30. Gao Y, Lee WM, Cheng CY. Thyroid hormone function in the rat testis. Front Endocrinol (Lausanne) 2014;5:188. 